\title{
Green synthesis of copper nanoparticles using a hydroalcoholic extract of Moringa oleifera leaves and assessment of their antioxidant and anti-microbial activities
}

\section{Prince Edwin Das, ${ }^{1}$ Imad A. Abu-Yousef, ${ }^{2 *}$ Amin F. Majdalawieh, ${ }^{2}$ Srinivasan Narasimhan, ${ }^{1 *}$ and Palmiro Poltronieri ${ }^{3 *}$}

\footnotetext{
${ }^{1}$ Asthagiri Herbal Research Foundation, 162A, Perungudi Industrial Estate, Perungudi, Chennai, India 600096. E-mails: prince.ahrf@gmail.com (P.E.D.); asthagiri.herbal@gmail.com (S.N.)

${ }^{2}$ Department of Biology, Chemistry and Environmental Sciences, American University of Sharjah, P.O. Box 26666, Sharjah, United Arab Emirates. E-mails: iabuyousef@aus.edu (I.A.A.Y); amajdalawieh@aus.edu (A.F.M)

${ }^{3}$ Institute of Sciences of Food Productions, CNR-ISPA, Lecce 73100, Italy. E-mail: palmiro.poltronieri@ispa.cnr.it (P.P.)
}

*Corresponding Authors. I.A. Abu-Yousef: Phone: (971) 6 5152410; Fax: (971) 6515 2450. E-mail: iabuyousef@aus.edu; S. Narasimhan: Phone: (91) 44 22397645; Fax: (91) 44 22397645. E-mail: narasimhan_s@yahoo.com; asthagiri.herbal@gmail.com; P. Poltronieri: palmiro.poltronieri@ispa.cnr.it; Tel.: (39) 83 2422609; Fax: (39) 832422620 


\section{Abstract}

The synthesis of metal nanoparticles using plant extracts is a very promising method in green synthesis. The medicinal value of Moringa oleifera leaves and the anti-microbial activity of metallic copper were combined in the present study to synthesize copper nanoparticles having a desirable added-value inorganic material. The use of a hydroalcoholic extract of $M$. oleifera leaves for the green synthesis of copper nanoparticles is an attractive method as it leads to the production of harmless chemicals and reduces waste. The total phenolic content in the $M$. oleifera leaves extract was $23.0 \pm 0.3 \mathrm{mg}$ gallic acid equivalent/g of dried $M$. oleifera leaves powder. The $M$. oleifera leaves extract was treated with a copper sulphate solution. A color change from brown to black indicates the formation of copper nanoparticles. Characterization of the synthesized copper nanoparticles was performed using UV-Vis spectrophotometer, FTIR spectrometer, TEM, SEM, and XRD. The synthesized copper nanoparticles have an amorphous nature and particle size of $35.8-49.2 \mathrm{~nm}$. We demonstrate that the M. oleifera leaves extract and the synthesized copper nanoparticles display considerable antioxidant activity. Moreover, the $M$. oleifera leaves extract and the synthesized copper nanoparticles exert potent anti-bacterial activity against Escherichia coli, Klebsiella pneumoniae, Staphylococcus aureus, and Enterococcus faecalis (MIC values for the extract: 500, 250, 250, and $250 \mu \mathrm{g} / \mathrm{mL}$; MIC values for the cooper nanoparticles: 500, 500, 500, and $250 \mu \mathrm{g} / \mathrm{mL}$, respectively). Similarly, the $M$. oleifera leaves extract and the synthesized copper nanoparticles exert relatively more potent anti-fungal activity against Aspergillus niger, Aspergillus flavus, Candida albicans, and Candida glabrata (MIC values for the extract: $62.5,62.5,125$, and $250 \mu \mathrm{g} / \mathrm{mL}$; MIC values for the cooper nanoparticles: $125,125,62.5$, and $31.2 \mu \mathrm{g} / \mathrm{mL}$, respectively). Our study reveals that the green synthesis of copper nanoparticles using a hydroalcoholic extract of $M$. oleifera leaves was successful. In addition, the 
synthesized copper nanoparticles can be potentially employed in the treatment of various microbial infections due to their potent antioxidant, anti-bacterial, and anti-fungal activities.

Keywords: Moringa oleifera; copper nanoparticles; polyphenolics; anti-bacterial; antifungal; antioxidant 


\section{Introduction}

Moringa oleifera (family Moringaceae) is known as the "tree of life". For thousands of years, it has been widely cultivated for its industrial and medicinal value. It is cultivated for its leaves and fruits, which are used in common man's kitchen. Almost all parts of the plant have been utilized in home remedies and traditional medicine [1]. M. oleifera leaves are edible and their vitamin and amino acid content make them a well-balanced diet [2]. The phenolic compounds present in $M$. oleifera leaves possess antioxidant properties and they are used in various medical applications [3]. It has been envisaged that plant compounds and their derivatives may be applied in several fields and industries such as textiles, fabrics, polymers for food and non-food applications, biomaterials for oral hygiene and prevention of dental caries, prevention of biofilm formation, and wrapping foil polymers for food packaging and food safety [4-10]. New materials based on the antimicrobial properties of plant compounds conjugated to silver nanoparticles and other nanoparticles-related technologies have been produced and studied [11-15].

Previous studies reported the successful use of active components of plant extracts (e.g. proteins, flavonoids and carboxylic groups of arabinose and galactose, reducing sugars, tannins, aliphatic amines, aliphatic alkenes of alkaloids, polysaccharides, aromatic amines, secondary alcohols, water-soluble heterocyclic components and saponins) in the synthesis of silver nanoparticles [16]. Typically, plant extracts possess intrinsic biological activities, which may further manifest in the biological activities of silver nanoparticles as a result of combining the two materials. Therefore, plant extracts can potentially be developed into novel nanomaterials with diverse biological activities [17]. Gold and silver nanoparticles were synthesized using leaves extracts of Erythrina suberosa (Roxb.), Paederia foetida, Acalypha indica, Cassia auriculata, Sorbus aucuparia, and Azadirachta indica, and their antimicrobial efficacy was evaluated [18-23]. Moreover, studies evaluated the in vitro 
assessment of both the antioxidant and antimicrobial activities of silver nanoparticles synthesized using various plant extracts [24-28]. In many cultures, people used to, and some still, drink water stored in copper vessels. Such water has a copper content of $177 \pm 16 \mathrm{ppb}$, which is well within the permissible limits according to the World Health Organization (WHO) [29]. Storing water in copper vessels purifies water by killing some species and strains of bacteria like Escherichia coli, as metallic copper surfaces rapidly and efficiently destroy bacteria by a contact-killing mode [30].

Our study attempts to bring together the properties of $M$. oleifera leaves' phytochemical constituents and the anti-microbial activity of copper. We aimed at the green synthesis and characterization of copper nanoparticles using a hydroalcoholic extract of $M$. oleifera leaves. Using different species of bacteria and fungi, we evaluated the potential anti-bacterial and anti-fungal activities of the $M$. oleifera leaves extract and the synthesized copper nanoparticles.

\section{Results and Discussion}

\subsection{Phytochemical Analysis of the M. oleifera Leaves Extract}

The qualitative evaluation of different chemical constituents in the $M$. oleifera leaves extract was performed using the test methods indicated in Table1. The presence is indicated with $(+)$. 
Table 1. Phytochemical analysis of the M. oleifera leaves extract.

\begin{tabular}{|c|c|c|}
\hline Functional group & Test method & M. oleifera leaves extract \\
\hline Alkaloids & Dragendroff's test & + \\
\hline Tannins & Ferric chloride & + \\
\hline Flavonoids & Shinoda test & + \\
\hline Steroids & Salkowski reaction & + \\
\hline Saponins & Foam test & + \\
\hline Polyphenols & Puncal-D & + \\
\hline Glycosides & Conc. $\mathrm{H}_{2}$ SO 4 and heat & + \\
\hline Carbohydrates & Anthrone test & + \\
\hline Proteins & Ninhydrin test & + \\
\hline Amino acids & Millon's test & + \\
\hline
\end{tabular}

The protein content in the $M$. oleifera leaves extract was estimated to be $0.1 \%$ of the dry leaves powder. The total phenolic content in M. oleifera leaves extract was $23 \%$ of the dry leaves powder. An earlier study demonstrated that alanine, tyrosine, lysine, and threonine are among the major amino acids present in the M. oleifera leaves extract [31]. The concoction of M. oleifera leaves extract contains isomers of ceffeoylquinic acid, isomers of feruloylquinic acid, tannins, gallic acid, and several flavonoids like quercetin, kaempferol (Suppl. Fig. 1) and their glycoside derivatives [32]. Collectively, these findings suggest that the M. oleifera leaves extract could serve as a nutritional supplement and a possible stabilizing agent for the formed copper nanoparticles.

From the total phenolic content estimation of the M. oleifera leaves extract before and after the reaction (Table 2), Scheme 1 is proposed. The total phenolic content of $60 \mathrm{mg}$ gallic acid equivalent from $10 \mathrm{~g}$ of dried $M$. oleifera leaves powder was used in the synthesis of $250 \mathrm{mg}$ 
of copper nanoparticles from $0.04 \mathrm{M}$ of copper (II) ion solution. The other reducing and binding chemical entities present in the concoction aid in the formation and stabilization of the synthesized copper nanoparticles.

Table 2.Estimation of total phenolic content before and after the synthesis of copper nanoparticles.

\begin{tabular}{|l|c|}
\hline \multicolumn{1}{|c|}{ Sample } & $\begin{array}{c}\text { Total phenolic content } \\
\text { (mg/g of dried leaves) }\end{array}$ \\
\hline $\begin{array}{l}\text { M. oleifera } \text { leaves extract } \\
\text { (before synthesis) }\end{array}$ & $23.0 \pm 0.3$ \\
\hline M. oleifera leaves extract \\
(after synthesis)
\end{tabular}

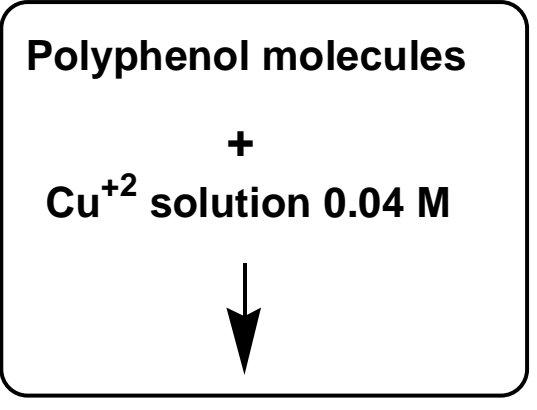

Copper nanoparticles

Scheme 1. Schematic representation of the synthesis of copper nanoparticles.

\subsection{Characterization}

\subsubsection{Size and Morphology of the Synthesized Copper Nanoparticles}

The synthesized copper nanoparticles were imaged using JEOL-TEM (JEM) (Figure 1) and EDS (Figure 2). 

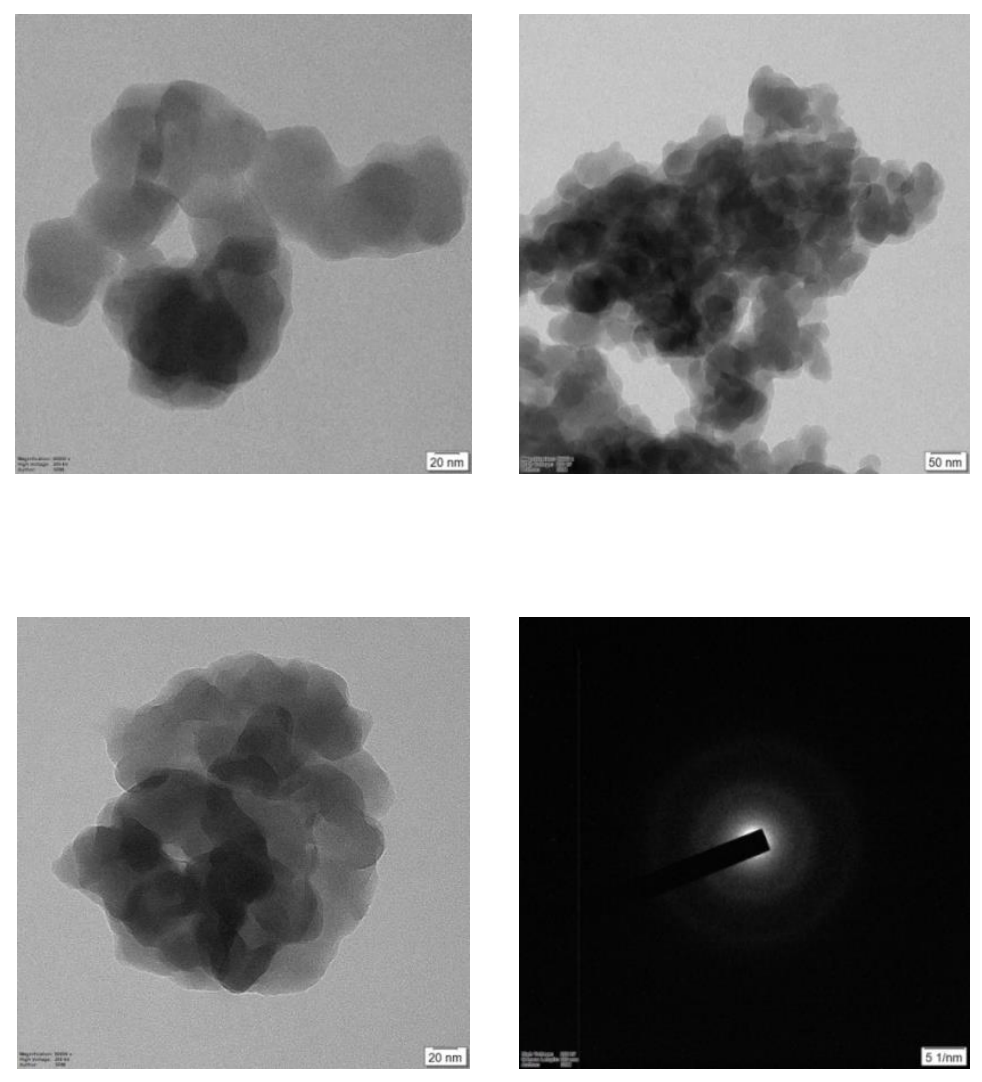

Figure1. JEOL-TEM (JEM) images of the synthesized copper nanoparticles.

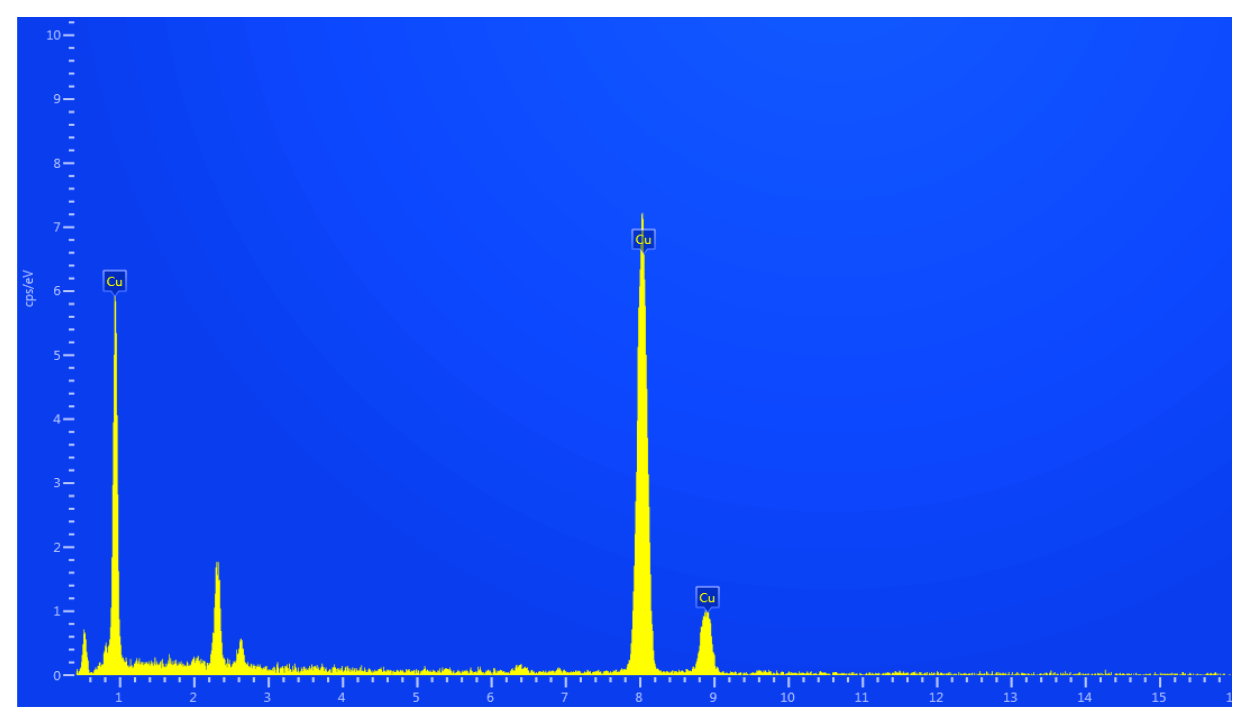

Figure 2.EDS spectrum with peaks corresponding to copper.

The synthesized copper nanoparticles were obtained in ethanol to give a colloidal solution.

The synthesized copper nanoparticles are amorphous in nature and they agglomerate upon 
storage. The energy dispersive X-ray spectroscopy analysis confirmed the presence of the elemental copper nanoparticles. The absence of other elemental peaks reflects the purity of the sample. The SEM images (Figure 3) indicate that the size of the synthesized copper particles is $35.8-49.2 \mathrm{~nm}$.

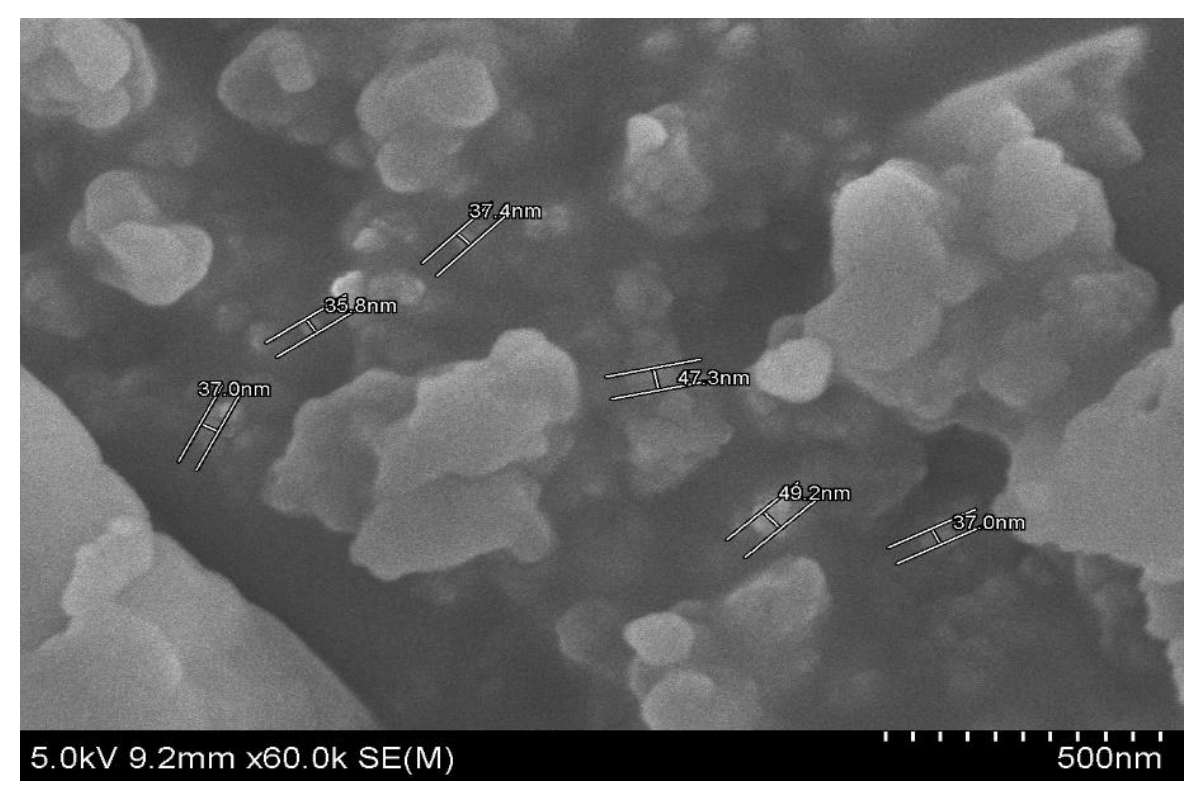

Figure 3.SEM image of the synthesized copper nanoparticles.

X-ray diffraction analysis confirms the amorphous nature of the synthesized copper nanoparticles (Figure 4). This substantiates the diffraction pattern observed in the JEOL-TEM (JEM) images (Figure 1), suggesting that the synthesized copper nanoparticles are amorphous in morphology. 


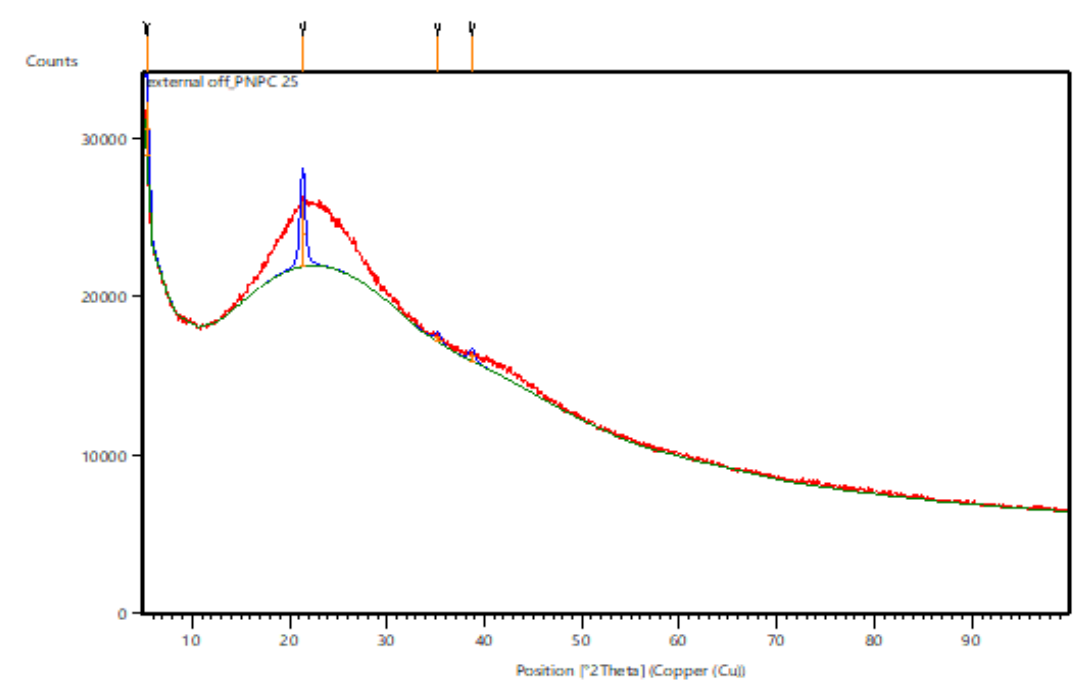

Figure 4. XRD spectrum of the synthesized copper nanoparticles.

\subsubsection{Fourier Transform Infrared Spectroscopy (FT-IR) of the M. oleifera Leaves Extract and the Synthesized Copper Nanoparticles}

The FT-IR spectra of the $M$. oleifera leaves extract and the synthesized copper nanoparticles are shown in Figure 5 and Figure 6, respectively. This vibration spectroscopy data can be used to understand the biomolecules involved in the synthesis of copper nanoparticles. The bands around $3400 \mathrm{~cm}^{-1}$ and $1630 \mathrm{~cm}^{-1}$ are broad in the $M$. oleifera leaves extract (Figure 5), corresponding to the vibration mode of hydroxyl group, mostly found in polyphenolic molecules such as tannins, flavonoids, and glycoside derivatives. The FT-IR spectrum of the synthesized copper nanoparticles (Figure 6) depicts a sharp band at $3431 \mathrm{~cm}^{-1}$, corresponding to the N-H vibration mode. This comparison shows the participation of the hydroxyl group in the synthesis of copper nanoparticles. Moreover, the binding characteristics of amino groups in the $M$. oleifera leaves extract are observed in Figure 5 and Figure 6 . This could be the reason for agglomeration of the synthesized copper nanoparticles to give an amorphous morphology. 


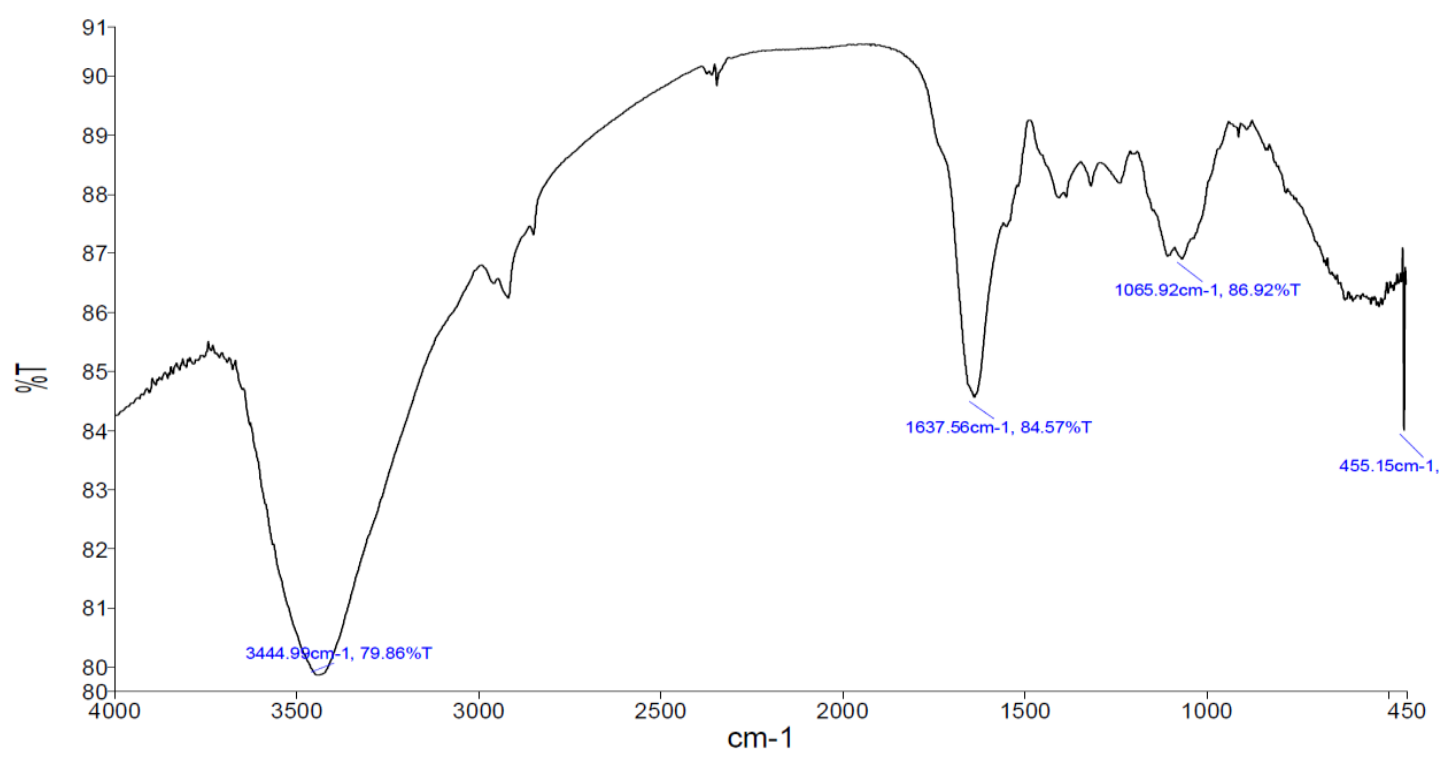

Figure 5. FT-IR spectrum of the M. oleifera leaves extract.

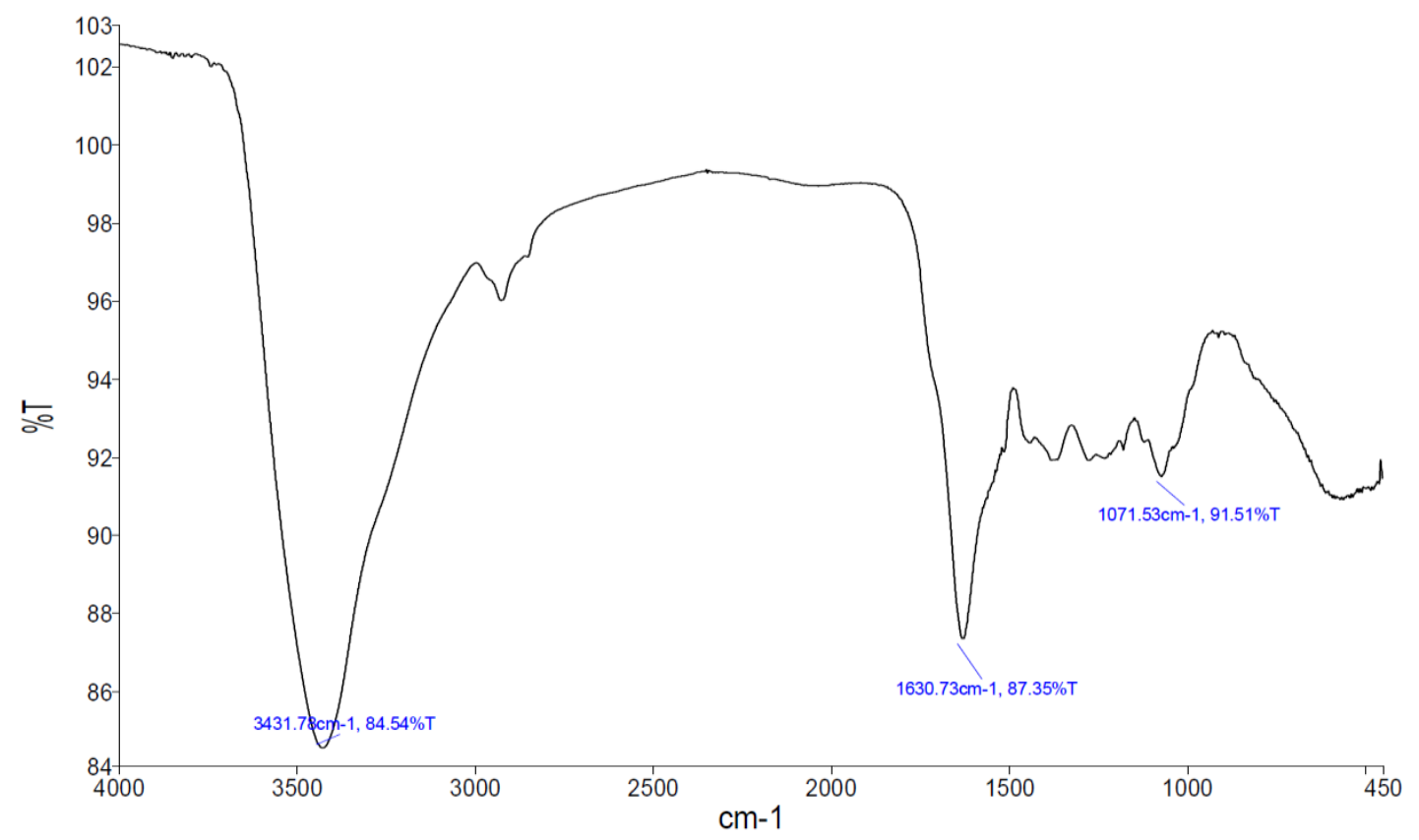

Figure 6. FT-IR spectrum of the synthesized copper nanoparticles. 


\subsubsection{UV-Vis Spectroscopy of the M. oleifera Leaves Extract and the Synthesized}

\section{Copper Nanoparticles}

The UV-Vis absorption spectrum of the $M$. oleifera leaves extract is shown in Figure $7, \lambda_{\max }$ at $390 \mathrm{~nm}$. The UV-Vis spectrum of the synthesized copper nanoparticles reconstituted in dimethyl sulfoxide (DMSO) solvent is shown in Figure $8, \lambda_{\max }$ at $260 \mathrm{~nm}$.

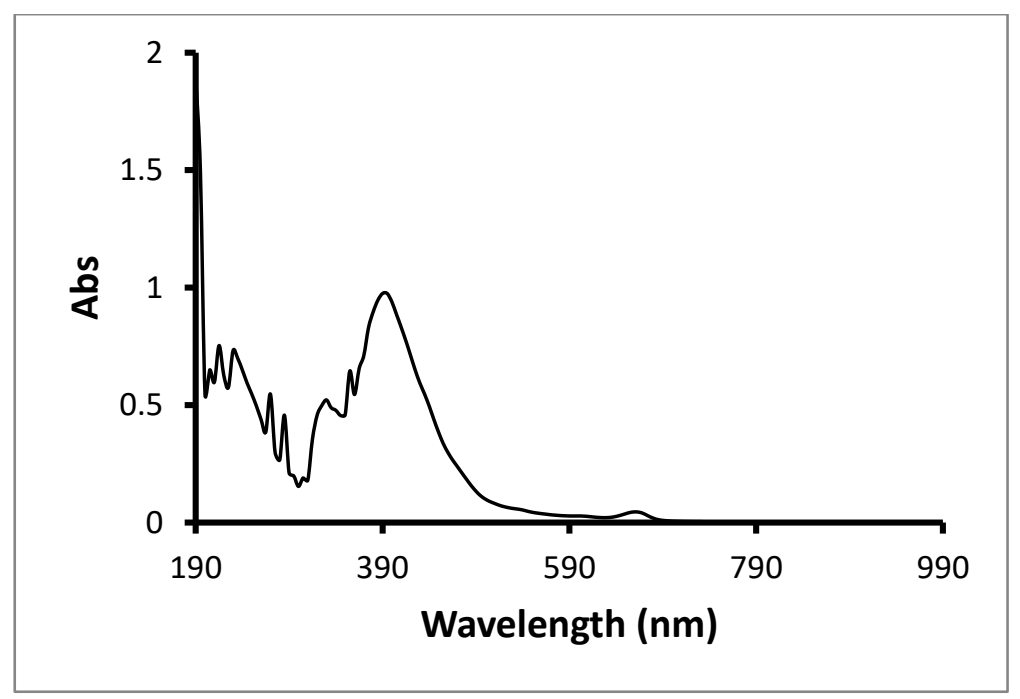

Figure 7. UV-Vis spectrum of the M. oleifera leaves extract.

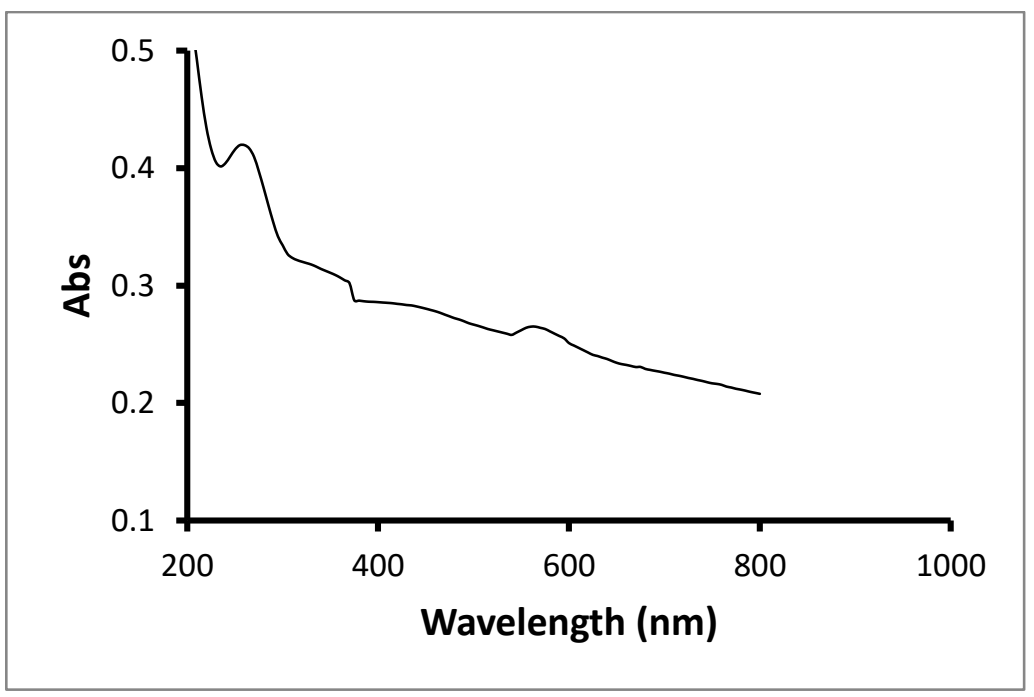

Figure 8. UV-Vis spectrum of the synthesized copper nanoparticles. 


\subsection{Antioxidant Activity of the M. oleifera Leaves Extract and the Synthesized Copper}

\section{Nanoparticles}

Using DPPH assay against ascorbic acid as a standard, the percentage of antioxidant activity of the $M$. oleifera leaves extract and the synthesized copper nanoparticles was assessed. As shown in Table 3, the $M$. oleifera leaves extract exerted considerable antioxidant activity, while the synthesized copper nanoparticles displayed a lower activity. These results were supported with total antioxidant capacity measured by phosphomolybdate assay (Table 4).

Table 3. Antioxidant activity percentage (AA\%) using DPPH assay.

\begin{tabular}{|l|c|c|c|c|c|}
\hline \multirow{2}{*}{ Sample } & \multicolumn{5}{c|}{ Amount $(\boldsymbol{\mu g})$} \\
\cline { 2 - 6 } & $\mathbf{1 0 0}$ & $\mathbf{2 0 0}$ & $\mathbf{3 0 0}$ & $\mathbf{4 0 0}$ & $\mathbf{5 0 0}$ \\
\hline Ascorbic acid (standard) & 34.4 & 55.1 & 67.2 & 75.8 & 84.4 \\
\hline M. oleifera leaves extract & 55.1 & 58.6 & 63.7 & 65.5 & 65.5 \\
\hline Copper nanoparticles & 12.0 & 13.7 & 17.2 & 20.6 & 29.3 \\
\hline
\end{tabular}

Table 4. Total antioxidant capacity(TAC) using phosphomolybdate assay.

\begin{tabular}{|l|c|c|c|c|c|}
\hline \multirow{2}{*}{\multicolumn{1}{|c|}{ Sample }} & \multicolumn{5}{|c|}{ Concentration( $\mu$ gs/mL) } \\
& \multicolumn{5}{|c|}{ Ascorbic acid equivalent) } \\
\cline { 2 - 6 } & $\mathbf{5 0}$ & $\mathbf{1 0 0}$ & $\mathbf{1 5 0}$ & $\mathbf{2 0 0}$ & $\mathbf{2 5 0}$ \\
\hline M. oleifera leaves extract & 32.5 & 65.0 & 102.5 & 132.5 & 172.5 \\
\hline Copper nanoparticles & 12.5 & 12.5 & 17.5 & 25.0 & 47.5 \\
\hline
\end{tabular}

\subsection{Anti-Bacterial Activity of the M. oleifera Leaves Extract and the Synthesized Copper}

\section{Nanoparticles}

The potential anti-bacterial activity of synthesized copper nanoparticles was evaluated against Escherichia coli, Klebsiella pneumoniae, Staphylococcus aureus, and Enterococcus faecalis. Streptomycin $(10 \mu \mathrm{g} / 500 \mu \mathrm{L})$ was used as a positive control, while water-ethanol (1:1) solution and DMSO solvent were used as negative controls for the M. oleifera leaves extract 
and the copper nanoparticles, respectively. The nutrient broth was also used as a negative control. The classification of these species of bacteria and their localization in the human body is given in Table 5. The minimum inhibitory concentration (MIC) values measured in presence of the $M$. oleifera leaves extract and the copper nanoparticles are given in Table 6. The growth of the indicated species of bacteria in presence of difference concentrations (7.8$1000 \mu \mathrm{g} / \mathrm{mL}$ ) of $M$. oleifera leaves extract and the copper nanoparticles is shown in Table 7. The resazurin microtiter assay plates for the $M$. oleifera leaves extract and the copper nanoparticles are shown in Figure 9. In presence of the M. oleifera leaves extract, the MIC values against Escherichia coli, Klebsiella pneumoniae, Staphylococcus aureus, and Enterococcus faecalis were found to be in the range of $250-500 \mu \mathrm{g} / \mathrm{mL}$ (Table 6). Very similar MIC values $(250-500 \mu \mathrm{g} / \mathrm{mL})$ were observed in presence of the synthesized copper nanoparticles (Table 6), indicating that the anti-bacterial activity was not lost in the process of green synthesis of the copper nanoparticles (Table 7 and Figure 9).

Table 5. Species of bacteria used for the anti-bacterial study.

\begin{tabular}{|c|c|c|c|}
\hline No. & Bacterial species & Classification & $\begin{array}{c}\text { Localization in the } \\
\text { human body }\end{array}$ \\
\hline 1 & Escherichia coli & Gram-negative & Lower intestine \\
\hline 2 & Klebsiella pneumoniae & Gram-negative & Flora in the mouth, \\
skin, and intestines
\end{tabular}


Table 6. Anti-bacterial activity (MIC values).

\begin{tabular}{|l|c|}
\hline \multicolumn{1}{|c|}{ Bacterial species } & MIC \\
\hline M. oleifera leaves extract & $(\boldsymbol{\mu g} / \mathbf{m L})$ \\
\hline Escherichia coli & 500 \\
\hline Klebsiella pneunomiae & 250 \\
\hline Staphylococcus aureus & 250 \\
\hline Enterococcus faecalis & 250 \\
\hline Copper nanoparticles & \\
\hline Escherichia coli & 500 \\
\hline Klebsiella pneunomiae & 500 \\
\hline Staphylococcus aureus & 250 \\
\hline Enterococcus faecalis & \\
\hline
\end{tabular}

Table 7. Anti-bacterial activity data (growth (+) and no growth (-)).

\begin{tabular}{|c|c|c|c|c|c|c|c|c|c|c|c|c|}
\hline \multirow[b]{2}{*}{ No. } & Bacterial species & \multicolumn{11}{|c|}{ Growth of bacteria } \\
\hline & $\begin{array}{c}\text { Concentration } \\
(\mu \mathrm{g} / \mathrm{mL})\end{array}$ & ఠ్రి & $\begin{array}{l}\text { త్ర } \\
\text { ฮิ }\end{array}$ & 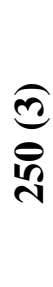 & 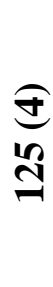 & $\begin{array}{c}\frac{10}{n} \\
\text { in } \\
\text { d }\end{array}$ & $\begin{array}{l}\text { co } \\
\frac{1}{m}\end{array}$ & 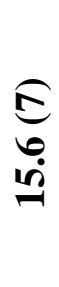 & 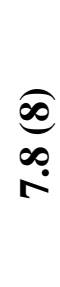 & 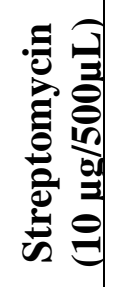 & 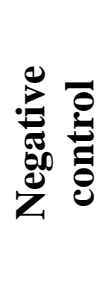 & 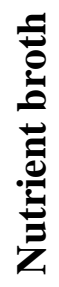 \\
\hline & \multicolumn{12}{|c|}{ M. oleifera leaves extract } \\
\hline 1 & Escherichia coli & - & - & + & + & + & + & + & + & - & + & + \\
\hline 2 & $\begin{array}{l}\text { Klebsiella } \\
\text { pneumoniae }\end{array}$ & - & - & - & + & + & + & + & + & - & + & + \\
\hline 3 & Staphylococcus & - & - & - & + & + & + & + & + & - & + & + \\
\hline
\end{tabular}




\begin{tabular}{|c|c|c|c|c|c|c|c|c|c|c|c|c|}
\hline & aureus & & & & & & & & & & & \\
\hline \multirow[t]{2}{*}{4} & $\begin{array}{l}\text { Enterococcus } \\
\text { faecalis }\end{array}$ & - & - & - & + & + & + & + & + & - & + & + \\
\hline & \multicolumn{12}{|c|}{ Copper Nanoparticles } \\
\hline 1 & Escherichia coli & - & - & + & + & + & + & + & + & - & + & + \\
\hline 2 & $\begin{array}{l}\text { Klebsiella } \\
\text { pneumoniae }\end{array}$ & - & - & + & + & + & + & + & + & - & + & + \\
\hline 3 & $\begin{array}{l}\text { Staphylococcus } \\
\text { aureus }\end{array}$ & - & - & + & + & + & + & + & + & - & + & + \\
\hline 4 & $\begin{array}{l}\text { Enterococcus } \\
\text { faecalis }\end{array}$ & - & - & - & + & + & + & + & + & - & + & + \\
\hline
\end{tabular}

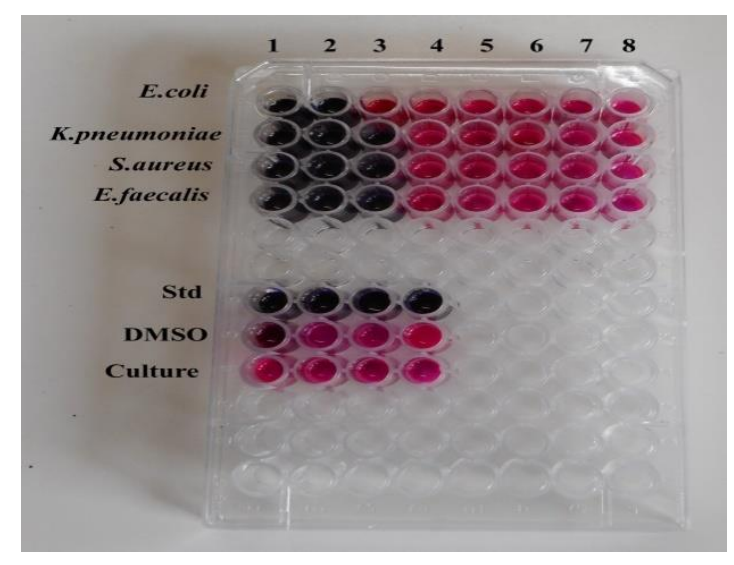

M. oleifera leaves extract

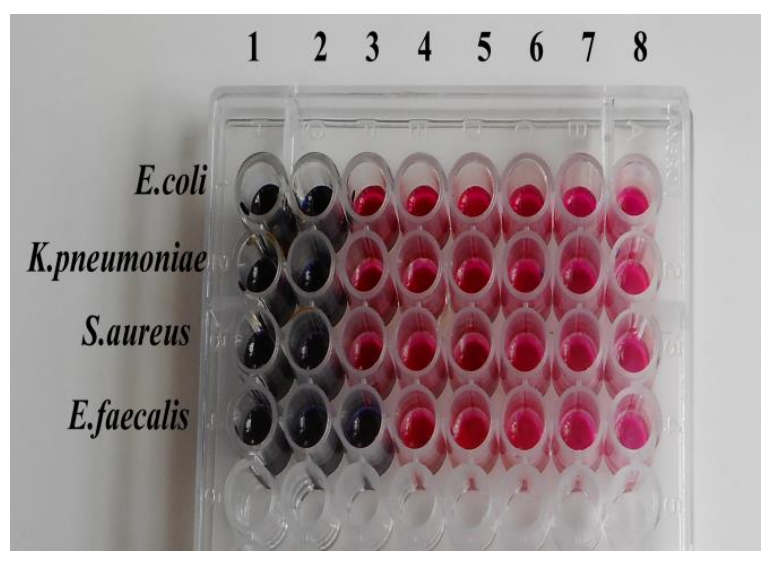

Copper nanoparticles

Figure 9. Resazurin microtiter assay plates for the $M$. oleifera leaves extract and the synthesized copper nanoparticles. 


\subsection{Anti-Fungal Activity of the M. oleifera Leaves Extract and the Synthesized Copper}

\section{Nanoparticles}

The potential anti-fungal activity of synthesized copper nanoparticles was evaluated against Aspergillus niger, Aspergillus flavus, Candida albicans, and Candida glabrata. Ketoconazole $(10 \mu \mathrm{g} / 500 \mu \mathrm{L})$ was used as a positive control, while water-ethanol (1:1) solution and DMSO solvent were used as negative controls for the $M$. oleifera leaves extract and the copper nanoparticles, respectively. The nutrient broth was also used as a negative control. The classification of these species of fungi and their localization in the human body is given in Table 8 . The minimum inhibitory concentration (MIC) values measured in presence of the $M$. oleifera leaves extract and the copper nanoparticles are given in Table 9. The growth of the indicated species of fungi in presence of difference concentrations $(7.8-1000 \mu \mathrm{g} / \mathrm{mL})$ of $M$. oleifera leaves extract and the copper nanoparticles is shown in Table 10. The resazurin microtiter assay plates for the $M$. oleifera leaves extract and the copper nanoparticles are shown in Figure 10. The copper nanoparticles displayed more effective anti-fungal activity against Candida albicans and Candida glabrata than the M. oleifera leaves extract (Table 9, Table 10, and Figure 10). In presence of the M. oleifera leaves extract, the MIC values against Aspergillus niger, Aspergillus flavus, Candida albicans, and Candida glabrata were found to be $62.5,62.5,125$, and $250 \mu \mathrm{g} / \mathrm{mL}$, respectively (Table 9). In presence of the synthesized copper nanoparticles, the MIC values against Aspergillus niger, Aspergillus flavus, Candida albicans, and Candida glabrata were found to be 125, 125, 62.5, and 31.2 $\mu \mathrm{g} / \mathrm{mL}$, respectively (Table 9). These findings indicate that the copper nanoparticles displayed more effective anti-fungal activity against Candida albicans and Candida glabrata compared to the $M$. oleifera leaves extract (Table 9, Table 10, and Figure 10). Moreover, it is concluded that the anti-fungal activity was not lost in the process of green synthesis of the copper nanoparticles. 
Table 8. Species of fungi used for the anti-fungal study.

\begin{tabular}{|c|c|c|}
\hline No. & Fungal species & Localization in the human body \\
\hline 1 & Aspergillus niger & Lungs \\
\hline 2 & Aspergillus flavus & Lungs, eyes, and ears \\
\hline 3 & Candida albicans & Flora in gastrointestinal tract \\
\hline 4 & Candida glabrata & Mucosal tissues \\
\hline
\end{tabular}

Table 9. Anti-fungal activity (MIC values).

\begin{tabular}{|l|c|}
\hline \multicolumn{1}{|c|}{ Fungal species } & MIC \\
& $(\mu \mathrm{g} / \mathbf{m L})$ \\
\hline M. oleifera leaves extract & \\
\hline Aspergillus niger & 62.5 \\
\hline Aspergillus flavus & 62.5 \\
\hline Candida albicans & 125 \\
\hline Candida glabrata & 250 \\
\hline Copper nanoparticles & \\
\hline Aspergillus niger & 125 \\
\hline Aspergillus flavus & 62.5 \\
\hline Candida albicans & 31.2 \\
\hline Candida glabrata & \\
\hline
\end{tabular}


Table 10. Anti-fungal activity data (growth (+) and no growth (-)).

\begin{tabular}{|c|c|c|c|c|c|c|c|c|c|c|c|c|}
\hline \multirow[b]{2}{*}{ No. } & Fungal species & \multicolumn{11}{|c|}{ Growth of fungi } \\
\hline & $\begin{array}{c}\text { Concentration } \\
(\mu \mathrm{g} / \mathrm{mL})\end{array}$ & $\begin{array}{l}\underset{\Xi}{8} \\
\stackrel{8}{8}\end{array}$ & $\begin{array}{l}\widehat{\overbrace{}} \\
8 \\
8\end{array}$ & 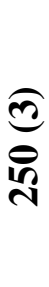 & 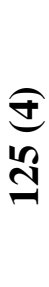 & 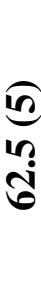 & $\underset{\frac{1}{3}}{\sigma}$ & 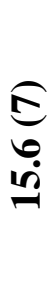 & $\begin{array}{l}\underset{\infty}{\infty} \\
\underset{\sim}{\infty}\end{array}$ & 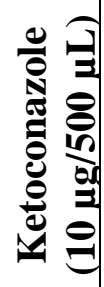 & 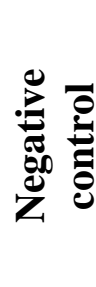 & 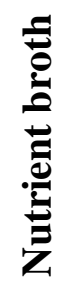 \\
\hline & \multicolumn{12}{|c|}{ M. oleifera leaves extract } \\
\hline 1 & Aspergillus niger & - & - & - & - & - & + & + & + & - & + & + \\
\hline 2 & Aspergillus flavus & - & - & - & - & - & + & + & + & - & + & + \\
\hline 3 & Candida albicans & - & - & - & - & + & + & + & + & - & + & + \\
\hline \multirow[t]{2}{*}{4} & Candida glabrata & - & - & - & + & + & + & + & + & - & + & + \\
\hline & \multicolumn{12}{|c|}{ Copper Nanoparticles } \\
\hline 1 & Aspergillus niger & - & - & - & - & + & + & + & + & - & + & + \\
\hline 2 & Aspergillus flavus & - & - & - & - & + & + & + & + & - & + & + \\
\hline 3 & Candida albicans & - & - & - & - & - & + & + & + & - & + & + \\
\hline 4 & Candida glabrata & - & - & - & - & - & - & + & + & - & + & + \\
\hline
\end{tabular}




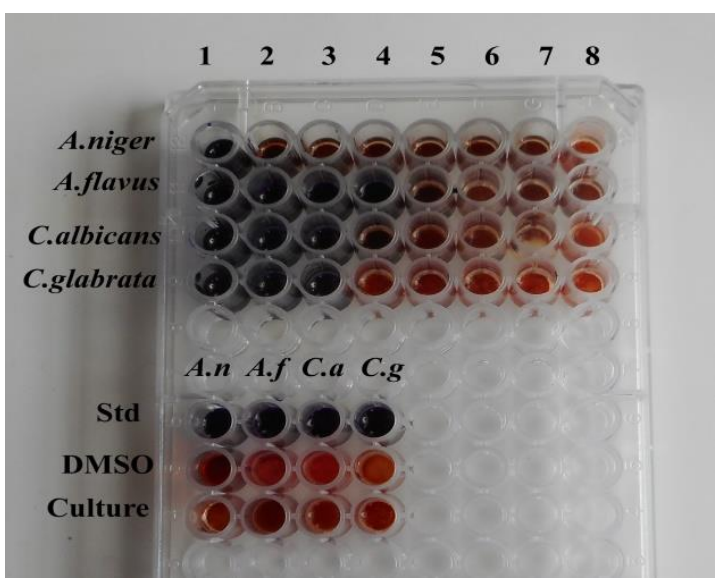

M. oleifera leaves extract

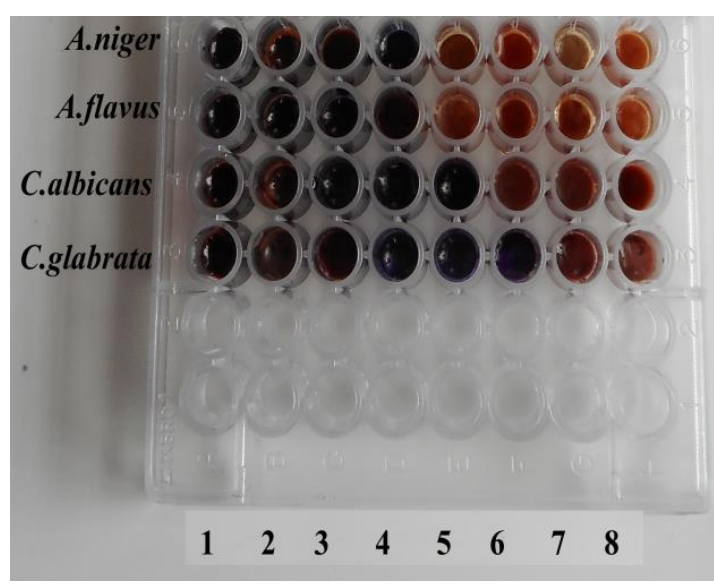

Copper nanoparticles

Figure 10. Resazurin microtiter assay plates for the $M$. oleifera leaves extract and the synthesized copper nanoparticles.

\section{Materials and Methods}

\subsection{Preparation of the M. oleifera Leaves Extract}

Fresh $M$. oleifera leaves were collected and shade-dried. The dried leaves were smoothly crushed. The M. oleifera leaves powder was stored at room temperature. $10 \mathrm{~g}$ of M. oleifera leaves powder was taken and soaked in $100 \mathrm{~mL}$ water-ethanol (1:1)solution. The mixture was macerated for $1 \mathrm{~h}$ and $M$. oleifera leaves extract was filtered through Whatman filter paper 1. The $M$. oleifera leaves extract was used immediately for the preparation of copper nanoparticles and other experimental analyses.

\subsection{Synthesis of the Copper Nanoparticles}

Copper sulfate pentahydrate $(1 \mathrm{~g})$ was dissolved in $20 \mathrm{~mL}$ de-mineralized water and added to $80 \mathrm{~mL}$ of $M$. oleifera leaves extract. The reaction mixture was stirred for $3 \mathrm{~h}$ at $60^{\circ} \mathrm{C}$. The synthesized copper nanoparticles were collected by centrifugation and repeatedly washed with de-mineralized water. The synthesized copper nanoparticles were dried at $105^{\circ} \mathrm{C}$ for $1 \mathrm{~h}$, and subsequently reconstituted in DMSO solvent. 


\subsection{Characterization of the Size and Morphology of the Synthesized Copper}

\section{Nanoparticles}

The completion of synthesis was characterized by UV-Vis spectroscopy. The formation of copper nanoparticles and the role of biomolecules in this synthesis were confirmed by BRUKER ALPHA-E FT-IR spectrometry. The crystalline nature of the synthesized copper nanoparticles was ascertained using Shimadzu XRD-6000 diffractometer. The size of the synthesized copper nanoparticles was measured by SEM using Quanta 200 FEG scanning electron microscope. The morphology assessment of the synthesized nanoparticles was done by JEOLJEM-2100 plus transmission electron microscopy. The sample was dispersed in ethanol, coated on the grid, and dried for TEM analysis, along with energy dispersive X-ray analysis.

\subsection{Phytochemical Analysis of the M. oleifera Leaves Extract}

The qualitative analysis of biomolecules present in the $M$. oleifera leaves extract was carried out for the presence of alkaloids, tannins, flavonoids, steroids, saponins, polyphenols, glycosides, carbohydrates, proteins, and amino acids. The total phenolic content in the $M$. oleifera leaves extract was estimated as gallic acid equivalent by Folin-Ciocalteu polyphenol assay [33].The protein content in the M. oleifera leaves extract was estimated by Lowry's method [34].

\subsection{Antioxidant Activity}

\subsubsection{DPPH Assay (Antioxidant Activity Percentage - AA\%)}

The antioxidant activity percentage (AA\%) (scavenging activity) of the M. oleifera leaves extract and the synthesized copper nanoparticles was assessed by DPPH free radical scavenging assay. $1 \mathrm{mg}$ of ascorbic acid (standard) was dissolved in $1 \mathrm{~mL}$ methanol. 
Different aliquots (serial dilution) of the ascorbic acid solution (0.1-0.5 mL), corresponding to $100-500 \mu \mathrm{g}$, were used for calibration. To each tube containing ascorbic acid solution, 1 $\mathrm{mL}$ of $0.1 \mathrm{mM}$ DPPH radical solution in ethanol was added, and the final volume was adjusted to $4 \mathrm{~mL}$ using ethanol. The stock solutions for the $M$. oleifera leaves extract and the synthesized copper nanoparticles were prepared by dissolving $1 \mathrm{mg}$ of each sample in $1 \mathrm{~mL}$ of an appropriate solvent (methanol for the $M$. oleifera leaves extract; DMSO for the synthesized copper nanoparticles). Different aliquots from the stock solutions $(0.1-0.5 \mathrm{~mL})$, corresponding to $100-500 \mu \mathrm{g}$, were added to all tubes except the blank tube (control). The volume in each tube was adjusted to $3 \mathrm{~mL}$ using ethanol. To each tube, $1 \mathrm{~mL}$ of $0.1 \mathrm{mM}$ DPPH radical solution in ethanol was added. The blank tube (control) was prepared by mixing $3 \mathrm{~mL}$ of ethanol and $1 \mathrm{~mL}$ of DPPH radical solution in ethanol. All tubes were incubated for $30 \mathrm{~min}$ at room temperature, and absorbance at $517 \mathrm{~nm}$ was recorded. AA\% was determined using the following formula:

$\mathrm{AA} \%=\{($ absorbance of blank $)-($ absorbance of sample $) /$ (absorbance of blank $)\} \mathrm{X} 100$

\subsubsection{Phosphomolybdenum Assay (Total Antioxidant Capacity - TAC)}

The total antioxidant capacity (TAC) of the $M$. oleifera leaves extract and the synthesized copper nanoparticles was assessed by phosphomolybdenum assay as ascorbic acid equivalent. $1 \mathrm{mg}$ of ascorbic acid (standard) was dissolved in $1 \mathrm{~mL}$ methanol. Different aliquots (serial dilution) of the ascorbic acid solution (0.1-0.5 mL), corresponding to 100-500 $\mu \mathrm{g}$, were prepared. The volume in each tube was adjusted to $4 \mathrm{~mL}$ using distilled water. The stock solutions for the $M$. oleifera leaves extract and the synthesized copper nanoparticles were prepared by dissolving $1 \mathrm{mg}$ of each sample in $1 \mathrm{~mL}$ of an appropriate solvent (methanol for the $M$. oleifera leaves extract; DMSO for the synthesized copper nanoparticles). Different aliquots from the stock solutions $(0.1-0.5 \mathrm{~mL})$, corresponding to $100-500 \mu \mathrm{g}$, were added to 
all tubes except the blank tube (control). The volume in each tube was adjusted to $3 \mathrm{~mL}$ using distilled water. To each tube, $1 \mathrm{~mL}$ of phosphomolybdenum reagent ( $0.6 \mathrm{M}$ sulphuric acid, 28 $\mathrm{mM}$ sodium phosphate, and $4 \mathrm{mM}$ ammonium molybdate) was added. The volume in each tube was adjusted to $4 \mathrm{~mL}$ using distilled water. After incubation for $90 \mathrm{~min}$ at $95^{\circ} \mathrm{C}$, absorbance at $695 \mathrm{~nm}$ was recorded. The calibration curve for the ascorbic acid solution (standard) was plotted for the absorbance at $695 \mathrm{~nm}$ against known amounts of ascorbic acid with the phosphomolybdate reagent, so as to express the TAC values as ppm equivalent of ascorbic acid. Using the ascorbic acid calibration curve, the TAC values for the M. oleifera leaves extract and the synthesized copper nanoparticles were calculated and expressed as ppm equivalent of ascorbic acid.

\subsection{Anti-Bacterial Activity using Resazurin Microtiter Assay}

The most rapid and inexpensive way to screen several microorganism isolates at the same time, with better correlation in comparison to other techniques, is the resazurin microtiter assay [35-37]. The resazurin solution was prepared by dissolving a 270mg tablet of resazurin in $40 \mathrm{~mL}$ of sterile distilled water. The test was carried out in 96-well plates under aseptic conditions. A volume of $100 \mu \mathrm{l}$ of sample containing $10 \mathrm{mg} / \mathrm{mL}$ was pipetted into the first well of the plate. To all other wells, $50 \mu \mathrm{L}$ of nutrient broth was added, and the tested sample was serially diluted. Subsequently, $10 \mu \mathrm{L}$ of resazurin solution and $10 \mu \mathrm{L}$ of bacterial suspension were added to each well. Each plate was wrapped loosely with cling film to prevent dehydration. The plates were incubated at $37^{\circ} \mathrm{C}$ for $18-24 \mathrm{~h}$. The color change was then assessed visually. A color change from purple to pink (or colorless) was recorded as positive, indicating cell growth (i.e. (+) means growth and (-) means no growth). The lowest concentration at which color change occurred was considered to be MIC. Streptomycin $(10 \mu \mathrm{g} / 500 \mu \mathrm{L})$ was used as a positive control, while water-ethanol (1:1) solution and DMSO 
solvent were used as negative controls for the $M$. oleifera leaves extract and the copper nanoparticles, respectively. The nutrient broth was also used as a negative control.

\subsection{Anti-Fungal Activity using Resazurin Microtiter Assay}

The resazurin solution was prepared by dissolving a $270 \mathrm{mg}$ tablet of resazurin in $40 \mathrm{~mL}$ of sterile distilled water. The test was carried out in 96-well plates under aseptic conditions. A volume of $100 \mu \mathrm{l}$ of sample containing $10 \mathrm{mg} / \mathrm{mL}$ was pipetted into the first well of the plate. To all other wells, $50 \mu \mathrm{L}$ of nutrient broth was added, and the tested sample was serially diluted. Subsequently, $10 \mu \mathrm{L}$ of resazurin solution and $10 \mu \mathrm{L}$ of fungal suspension were added to each well. Each plate was wrapped loosely with cling film to prevent dehydration. The plates were incubated at $37^{\circ} \mathrm{C}$ for $18-24 \mathrm{~h}$. The color change was then assessed visually. A color change from purple to pink (or colorless) was recorded as positive, indicating cell growth (i.e. (+) means growth and (-) means no growth). The lowest concentration at which color change occurred was considered to be MIC. Ketoconazole $(10 \mu \mathrm{g} / 500 \mu \mathrm{L})$ was used as a positive control, while water-ethanol (1:1) solution and DMSO solvent were used as negative controls for the $M$. oleifera leaves extract and the copper nanoparticles, respectively. The nutrient broth was also used as a negative control.

\section{Conclusion}

The green synthesis of copper nanoparticles using a hydroalcoholic extract of M. oleifera leaveswas successful. The formation of copper nanoparticles and the role of biomolecules in this synthesis were confirmed by UV-Vis absorption and FT-IR spectrometry. The energy dispersive X-ray spectroscopy analysis confirmed the presence of the elemental copper nanoparticles. The crystalline nature of the synthesized copper nanoparticles was ascertained by XRD. Using SEM, the particle size of the synthesized copper nanoparticles was measured 
to be 35.8-49.2 $\mathrm{nm}$. Using TEM with EDS, the synthesized copper nanoparticles were shown to have an amorphous morphology.Our study reveals that the M. oleifera leaves extract and the synthesized copper nanoparticles display considerable antioxidant activity, although the latter was relatively less influential. We also demonstrate that the $M$. oleifera leaves extract and the synthesized copper nanoparticles exert potent anti-bacterial activity against Escherichia coli, Klebsiella pneumoniae, Staphylococcus aureus, and Enterococcus faecalis, with MIC values in the range of $250-500 \mu \mathrm{g} / \mathrm{mL}$. Similarly, the $M$. oleifera leaves extract and the synthesized copper nanoparticles exert relatively more potent anti-fungal activity against Aspergillus niger, Aspergillus flavus, Candida albicans, and Candida glabrata, with MIC values in the range of $62.5-250 \mu \mathrm{g} / \mathrm{mL}$ and $31.2-125 \mu \mathrm{g} / \mathrm{mL}$, respectively. Indeed, the antifungal activity of the synthesized copper nanoparticles is more effective than that of the $M$. oleifera leaves extract against Candida albicans and Candida glabrata. We also conclude that the anti-bacterial and anti-fungal activities were not lost in the process of green synthesis of the copper nanoparticles. These findings suggest that the synthesized copper nanoparticles can be a promising therapeutic candidate for the treatment of various bacterial, and particularly, fungal infections such as candidiasis.

\section{Acknowledgments}

We acknowledge the HRTEM Facility at SRMIST set up with support from MNRE (Project No. 31/03/2014-15/PVSE-R\&D), Government of India. We acknowledge Nanotechnology Research Centre (NRC), SRMIST for providing the research facilities. 


\section{Author Contributions}

N.S., I.A.A.Y, A.F.M., and P.P. designed the experiments and supervised their execution.

P.E.D. performed the preparation of the M. oleifera leaves extract and the green synthesis of the copper nanoparticles. P.E.D. performed the phytochemical and biological analyses. P.E.D., N.S., I.A.A.Y, A.F.M., and P.P. performed data analyses of the experimental assays. All authors contributed to manuscript writing and preparation.

\section{Conflicts of Interest}

The authors declare no conflicts of interest. 


\section{References}

1. Rathi, B.S.; Bodhankar, S.L.; Baheti, A.M. Evaluation of aqueous leaves extract of Moringa oleifera Linn for wound healing in albino rats. Indian J. Exp. Biol. 2006, 44, 898-901.

2. Ogbe, A.O.; Affiku, J.P. Proximate study, mineral and anti-nutrient composition of Moringa oleifera leaves harvested from Lafia, Nigeria: potential benefits in poultry nutrition and health. JMBFS 2011, 1(3), 296-308.

3. Siddhuraju, P.; Becker, K. Antioxidant properties of various solvent extracts of total phenolic constituents from three different agroclimatic origins of drumstick tree (Moringa oleifera Lam.) leaves. J. Agric. Food Chem. 2003, 51, 2144-2155.

4. Fitzgerald, D.J.; Stratford, M.; Gasson, M.J.; Ueckert, J.; Bos, A.; Narbad, A. Mode of antimicrobial action of vanillin against Escherichia coli, Lactobacillus plantarum and Listeria innocua. J. App. Microbiol. 2004, 97, 104-113.

5. Narasimhan, S.; Maheshwaran, S.; Abu-Yousef, I.A.; Majdalawieh, A.F.; Rethavathi, J.; Das, P.E.; Poltronieri, P. Anti-bacterial and anti-fungal activity of xanthones obtained via semi-synthetic modification of $\alpha$-mangostin from Garcinia mangostana. Molecules 2017, 22(2), E275.

6. Suwantong, O.; Pankongadisak, P.; Deachathai, S.; Supaphol, P. Electrospun poly(1-lactic acid) fiber mats containing crude Garcinia mangostana extracts for use as wound dressings. Polym. Bull. 2014, 71, 925-949.

7. Lakouraj, M.M.; Rahpaima, G.; Mohseni, M. Synthesis, characterization, metal sorption, and biological activities of organosoluble and thermally stable azoxanthone-based polyester. Polym. Adv. Tech. 2015, 26, 3, 234-244. 
8. Mun, S.H.; Joung, D.K.; Kim, Y.S.; Kang, O.H.; Kim, S.B.; Seo, Y.S.; Kwon, D.Y. Synergistic antibacterial effect of curcumin against methicillin-resistant Staphylococcus aureus. Phytomedicine 2013, 20, 714-718.

9. Dogra, N.; Choudhary, R.; Kohli, P.; Haddock, J.D.; Makwana, S.; Horev, B.; Vinokur, Y.; Droby, S.; Rodov, V. Polydiacetylene nanovesicles as carriers of natural phenylpropanoids for creating antimicrobial food-contact surfaces. J. Agr. Food Chem. 2015, 63, 2557-2565.

10. Horev, B.; Sela, S.; Vinokur, Y.; Gorbatsevich, E.; Pinto, R.; Rodov, V. The effects of active and passive modified atmosphere packaging on the survival of Salmonella enterica serotype Typhimurium on washed romaine lettuce leaves. Food Res. Int. 2012, 45, 11291132.

11. Ravichandran, M.; Hettiarachchy, N.S.; Ganesh, V.; Ricke, S.C.; Singh, S. Enhancement of antimicrobial activities of naturally occurring phenolic compounds by nanoscale delivery against Listeria monocytogenes, Escherichia coli O157:H7 and Salmonella Typhimurium in broth and chicken meat system. J. Food Safety 2011, 31, 462-471.

12. Fadida, T.; Kroupitski, Y.; Peiper, U.M.; Bendikov, T.; Sela, S.; Poverenov, E. Airozonolysis to generate contact active antimicrobial surfaces: activation of polyethylene and polystyrene followed by covalent graft of quaternary ammonium salts. Colloids Surf. B Biointerfaces 2014, 122, 294-300.

13. Meridor, D.; Gedanken, A. Preparation of enzyme nanoparticles and studying the catalytic activity of the immobilized nanoparticles on polyethylene films. Ultrason. Sonochem. 2013, 20, 425-431.

14. Reidy, B.; Haase, A.; Luch, A.; Dawson, K.A.; Lynch, I. Mechanisms of silver nanoparticle release, transformation and toxicity: a critical review of current knowledge and recommendations for future studies and applications. Materials 2013, 6, 2295-2350. 
15. Malka, E.; Perelshtein, I.; Lipovsky, A.; Shalom, Y.; Naparstek, L.; Perkas, N.; Patick, T.; Lubart, R.; Nitzan, Y.; Banin, E.; Gedanken, A. Eradication of multi-drug resistant bacteria by a novel Zn-doped $\mathrm{CuO}$ nanocomposite. Small 2013, 9, 4069-4076.

16. Borase, H.P.; Salunke, B.K.; Salunkhe, R.B.; Patil, C.D.; Hallsworth, J.E.; Kim, B.S.;Patil, S.V. Plant extract: a promising bio-matrix for ecofriendly, controlled synthesis of silver nanoparticles. Appl. Biochem. Biotechnol. 2014, 17, 1-29.

17. Park, Y. A new paradigm shift for the green synthesis of antibacterial silver nanoparticles utilizing plant extracts. J. Korean Soc. Toxicol. Res. 2014, 30(3), 169-178.

18. Mohanta, Y.K.; Panda, S.K.; Jayabalan, R.; Sharma, N.; Bastia, A.K.; Mohanta, T.K. Antimicrobial, antioxidant and cytotoxic activity of silver nanoparticles synthesized by leaf extract of Erythrina suberosa (Roxb.). Front. Mol. Biosci. 2017, 4, 1-9.

19. Madhavaraj, L.; Sethumadhavan, V.V.; Geun, H.G.; Mathur, N.K.; Si, W.K. Synthesis, characterization and evaluation of antimicrobial efficacy of silver nanoparticles using Paederia foetida leaf extract. Intern. Res. J. Biol. Sci. 2013, 15(3), 76-80.

20. Krishnaraj, C.; Jagan, E.G.; Rajasekar, S.; Selvakumar, P.; Kalaichelvan, P.T.; Mohan, N. Synthesis of silver nanoparticles using Acalypha indica leaf extracts and its antibacterial activity against water borne pathogens. Colloids Surf. B: Biointerfaces 2010, 76, 50-56.

21. Parveen, A.; Roy, A.S.; Rao, S. Biosynthesis and characterization of silver nanoparticles from Cassia auriculata leaf extract and in vitro evaluation of antimicrobial activity. Intern. J. Appl. Biol. Pharmaceutical Technol. 2012, 3(2), 222-228.

22. Dubey, S.P.; Lahtinen, M.; Särkkä, H.; Sillanpää, M. Bioprospective of Sorbus aucuparia leaf extract in development of silver and gold nanocolloids. Colloids Surf. B: Biointerfaces 2010, 80(1), 26-33. 
23. Gavhane, A.J.; Padmanabhan, P.; Kamble, S.P.; Jangle, S.N. Synthesis of silver nanoparticles using the extracts of neem leaf and triphala and the evaluation of their antimicrobial activities. Int. J. Pharm. Biol. Sci. 2012, 3, 88-100.

24. Ahmed, S.; Ahmad, M.; Swami, B.L.; Ikram, S. A review on plants extract mediated synthesis of silver nanoparticles for antimicrobial applications: a green expertise. $J . A d v$. Res. 2016, 7, 17-28.

25. Mohanta, Y.K.; Panda, S.K.; Biswas, K.; Tamang, A.; Bandyopadhyay, J.; De, D. Biogenic synthesis of silver nanoparticles from Cassia fistula (Linn.): in vitro assessment of their antioxidant, antimicrobial and cytotoxic activities. IET Nanobiotechnol. 2016, $10(6), 438-444$.

26. Mariselvam, R.; Ranjitsingh, A.J.;Usha Raja Nanthini, A.;Kalirajan, K.; Padmalatha, C.; Mosae Selvakumar, P. Green synthesis of silver nanoparticles from the extract of the inflorescence of Cocos nucifera (Family: Arecaceae) for enhanced antibacterial activity. Spectrochim. Acta A Mol. Biomol. Spectrosc. 2014,129, 537-541.

27. Balashanmugam, P.; Caral Dinesh, R.; Manivasagan, V.; Ramesh Babu, N.G.; Kalaichelvan, P.T. Extracellular biosynthesis of silver nanoparticles using Cassia fistula extract and in vitro antimicrobial studies. J. Pharm. Res. 2014, 8(2), 187-191.

28. Majeed, A.; Ullah, W.; Anwar, A.W.; Shuaib, A.; Ilyas, U.; Khalid, P. Cost-effective biosynthesis of silver nanoparticles using different organs of plants and their antimicrobial applications: a review. Mater. Technol. 2016, 33, 313-320.

29. Sudha, V.B.; Ganesan, S.; Pazhani, G.P.; Ramamurthy, T.; Nair, G.B.; Venkatasubramanian, P. Storing drinking-water in copper pots kills contaminating diarrhoeagenic bacteria. J. Health Popul.Nutr. 2012, 30(1), 17-21. 
30. Espírito-Santo, C.; Lam, E.W.; Elowsky, C.G.; Quaranta, D.; Domaille, D.W.; Chang, C.J.; Grass, G. Bacterial killing by dry metallic surfaces. App. Environ.Microbiol. 2011, 77, 794-802.

31. Moyo, B.; Masika, P.J.; Hugo, A.; Muchenje, V. Nutritional characterization of Moringa (Moringa oleifera Lam.) leaves. Afr. J. Biotechnol. 2011, 10(60), 12925-12933.

32. Rodríguez-Pérez, C.; Quirantes-Piné, R.; Fernández-Gutiérrez, A., Segura-Carretero, A. Optimization of extraction method to obtain a phenolic compounds-rich extract from Moringa oleifera Lam leaves. Ind. Crop. Prod. 2015, 66, 246-254.

33. Koşar, M.; Dorman, H.J.D.; Hiltunen, R. Effect of an acid treatment on the phytochemical and antioxidant characteristics of extracts from selected Lamiaceae species. Food Chem. 2005, 91, 525-533.

34. Lowry, O.H.; Roserbough, N.J.; Farr, A.L.; Randall, R.J. Protein measurement with the folin phenol reagent. J. Biol. Chem. 1951, 193, 265-275.

35. Monteiro, M.C.; de la Cruz, M.; Cantizani, J.; Moreno, C.; Tormo, J.R.; Mellado, E.; De Lucas, J.R.; Asensio, F.; Valiante, V.; Brakhage, A.A.; Latgé, J.P.; Genilloud, O.; Vicente F. A new approach to drug discovery: high-throughput screening of microbial natural extracts against Aspergillus fumigatus using resazurin. J. Biomol. Screen. 2012, 17(4), $542-549$.

36. Sarker, S.D.; Nahar, L.; Kumarasamy, Y. Microtitre plate-based antibacterial assay incorporating resazurin as an indicator of cell growth, and its application in the in vitro antibacterial screening of phytochemicals. Methods 2007, 42(4), 321-324.

37. Hudman, D.A.; Sargentini, N.J. Resazurin-based assay for screening bacteria for radiation sensitivity. Springerplus 2013, 2(1), 55. 